\title{
A New Nested Allele-Specific Multiplex Polymerase Chain Reaction Method for Haplotyping of VKORC1 Gene to Predict Warfarin Sensitivity
}

\author{
Yung An Chua, ${ }^{1}$ Wan Zaidah Abdullah, ${ }^{2}$ Zukurnai Yusof, ${ }^{3}$ and Siew Hua Gan ${ }^{4}$ \\ ${ }^{1}$ Department of Pharmacology, School of Medical Sciences, Universiti Sains Malaysia, 16150 Kubang Kerian, Kelantan, Malaysia \\ ${ }^{2}$ Department of Haematology, School of Medical Sciences, Universiti Sains Malaysia, 16150 Kubang Kerian, Kelantan, Malaysia \\ ${ }^{3}$ Invasive Cardiology Laboratory, Hospital Universiti Sains Malaysia, 16150 Kubang Kerian, Kelantan, Malaysia \\ ${ }^{4}$ Human Genome Center, School of Medical Sciences, Universiti Sains Malaysia, 16150 Kubang Kerian, Kelantan, Malaysia
}

Correspondence should be addressed to Siew Hua Gan; shgan@kck.usm.my

Received 26 December 2013; Revised 23 February 2014; Accepted 25 February 2014; Published 30 March 2014

Academic Editor: Stelvio M. Bandiera

Copyright (C) 2014 Yung An Chua et al. This is an open access article distributed under the Creative Commons Attribution License, which permits unrestricted use, distribution, and reproduction in any medium, provided the original work is properly cited.

\begin{abstract}
The vitamin K epoxide reductase complex 1 gene (VKORC1) is commonly assessed to predict warfarin sensitivity. In this study, a new nested allele-specific multiplex polymerase chain reaction (PCR) method that can simultaneously identify single nucleotide polymorphisms (SNPs) at VKORC1 381, 861, 5808, and 9041 for haplotype analysis was developed and validated. Extracted DNA was amplified in the first PCR DNA, which was optimized by investigating the effects of varying the primer concentrations, annealing temperature, magnesium chloride concentration, enzyme concentration, and the amount of DNA template. The amplification products produced from the first round of PCR were used as templates for a second PCR amplification in which both mutant and wild-type primers were added in separate PCR tubes, followed by optimization in a similar manner. The final PCR products were resolved by agarose gel electrophoresis and further analysed by using a VKORC1 genealogic tree to infer patient haplotypes. Fifty patients were identified to have $\mathrm{H} 1 \mathrm{H} 1$, one had $\mathrm{H} 1 \mathrm{H} 2$, one had $\mathrm{H} 1 \mathrm{H} 7,31$ had either $\mathrm{H} 1 \mathrm{H} 7$ or $\mathrm{H} 1 \mathrm{H} 9$, one had $\mathrm{H} 1 \mathrm{H} 9$, eight had $\mathrm{H} 7 \mathrm{H} 7$, and one had $\mathrm{H} 8 \mathrm{H} 9$ haplotypes. This is the first method that is able to infer VKORC1 haplotypes using only conventional PCR methods.
\end{abstract}

\section{Introduction}

Warfarin is a blood-thinning drug that has been studied extensively and confirmed to show interindividual variability in efficacy due to genetic polymorphism. To date, sensitivity to warfarin has been significantly associated with the cytochrome P450 (CYP2C9) and vitamin K epoxide reductase complex 1 (VKORC1) genes [1-3]. Many studies have provided convincing evidence that the combined genotyping of CYP2C9 and VKORC1 helps to predict the appropriate warfarin dosage for a patient and reduces the incidence of adverse effects $[4,5]$. Based on these data, the FDA has changed its warfarin use guidelines to recommend genotyping to aid in initial warfarin dosing [6].

Several researchers have already developed PCR methods for the simultaneous detection of multiple CYP2C9 single nucleotide polymorphisms (SNPs), which can be very useful in clinical practice. In contrast, VKORC1 SNPs have only been studied relatively recently $[7,8]$ and multiplex PCR methods for these SNPs are not yet available. At present, the most comprehensive method for determining warfarin sensitivity based on the VKORC1 gene is by identifying whether an individual carries the $\mathrm{H} 1, \mathrm{H} 2, \mathrm{H} 7, \mathrm{H} 8$, or $\mathrm{H} 9$ haplotype; at least four SNPs are required to delineate the haplotypes [9]. The $\mathrm{H} 1$ and $\mathrm{H} 2$ haplotypes are correlated with a low warfarin dosage requirement, while $\mathrm{H} 7, \mathrm{H} 8$, and $\mathrm{H} 9$ are correlated with a higher dosage requirement.

Due to interethnic genetic variability, Lee et al. have suggested that, for an Asian population, a single VKORC1 SNP is sufficient to delineate whether an individual will require a low or high dosage of warfarin [10]. A retrospective study using only VKORC1 381 as predictor of VKORC1 
haplotypes has been validated [11]. However, the dosing model is still inadequate; although it successfully explains $60.2 \%$ of warfarin dosing variability, the model overestimates the required daily warfarin dose by $50 \%$ on average in 11 out of 108 subjects.

PCR methods for other VKORC1 SNPs, especially VKORC13673 (also known as VKORC1-1639G>A), have also been described extensively [12-14]. In addition, a capillary electrophoresis method that can simultaneously detect SNPs in CYP2C9, VKORC1, and gamma-glutamyl carboxylase $(G G C X)$ has been developed. However, all of these methods were designed to detect only a single VKORC1 SNP [15], and the detection of GGCX SNPs may not be necessary due to its limited utility in determining warfarin dosage [16]. There exist real-time PCR methods coupled with fluorescentlabeled probes that can singly detect $C Y P 2 C 9 * 2, C Y P 2 C 9 * 3$, and a VKORC1 $[17,18]$ which are tedious when carried out. Single multiplex real-time PCR methods that can simultaneously detect $C Y P 2 C 9 * 3$ and a VKORC1 SNP [19] also exist. However, even though real-time PCR analysis is rapid and more sensitive than conventional PCR method, it requires a more stringent sample processing and not all laboratories were equipped with real-time thermal cyclers which tend to be more expensive than conventional thermal cycler. Moreover, real-time PCR methods are only able to detect a single VKORC1 variant at one time. Therefore, in an effort to generate a simpler method without sacrificing the prediction accuracy of $V K O R C 1$, we developed a new nested allelespecific multiplex polymerase chain reaction (PCR) method that is able to simultaneously genotype the VKORC1 381, 861, 5808, and 9041 SNPs.

\section{Materials and Methods}

2.1. Source of DNA. The method was approved by the Research Ethics Committee (Human) of Universiti Sains Malaysia. Malay patients $(n=93)$ between 32 and 85 years old who received warfarin therapy were recruited from the Specialised Medicine Clinic of the Hospital Universiti Sains Malaysia between March 2008 and October 2010. Blood $(3 \mathrm{~mL})$ was drawn from each of the subjects after signing written informed consents. DNA was extracted from $200 \mu \mathrm{L}$ of the collected blood using a QIAamp DNA Blood Mini Kit (Qiagen, Hilden).

2.2. Primer Design. To increase the specificity of the PCR amplification, a two-step PCR was performed. The first step PCR (PCR1) primer pair was designed to decrease the overall length of the genomic templates, while the second step PCR (PCR2) primer pair was designed to amplify DNA sections within the PCR1 product containing the SNP sites. To differentiate between wild-type and mutant genotype, the $3^{\prime}$-ends of the wild-type and mutant PCR2 primers were designed to have one nucleotide difference. The wild-type primer amplifies only samples for wild-type alleles, and the opposite is true for the mutant primer.

The specificity of each of the primers was checked using a Basic Local Alignment Tool (BLAST) from NCBI. Highly specific forward and reverse primer candidates were paired with one another and were checked for their amplification specificity and melting temperature $\left(T_{m}\right)$ in silico using Primer-BLAST from NCBI. The possible formation of crossdimers was further checked using the NetPrimer Java application (http://www.premierbiosoft.com/). Only primers that were predicted to specifically amplify the SNP sites with similar melting temperature $\left(T_{m}\right)$ and yield a reasonable product size were selected for the development of the VKORC1 amplification method. The primers selected for PCR1 and PCR2 are listed in Table 2.

2.3. Multiplex PCR Optimisation. Polymerase chain reaction method optimisation was first carried out for PCR1 using DNA templates from only a single subject. The method optimisation consisted of a series of investigations that tested for the optimum primer concentrations, annealing temperature, magnesium chloride $\left(\mathrm{MgCl}_{2}\right)$ concentration, and enzyme concentration. The optimised PCR1 products were then diluted 200 times before being used as the DNA templates for PCR2 method optimisation. An individual sample from PCR1 was divided into two portions in separate tubes for PCR2 amplification, in which each tube amplifies mutant and wild-type variants, respectively.

The stock reagents used for both PCRs were 10X Taq buffer (Fermentas, Vilnius), 5.0 U/ $\mu \mathrm{L}$ Taq polymerase (Fermentas, Vilnius), $25 \mathrm{mM} \mathrm{MgCl}_{2}$ (Fermentas, Vilnius), $10 \mathrm{mM}$ dNTP (Fermentas, Vilnius), $10 \mu \mathrm{M}$ forward and reverse primers, respectively (1st Base Laboratory, Selangor), and autoclaved distilled water. The total reaction volume of a single PCR amplification was $20 \mu \mathrm{L}$. All PCR reactions were performed in a MyCycler Thermal Cycler (Bio-Rad Laboratories, Hercules). The optimised PCR1 and PCR2 methods were then tested for reproducibility in samples from 20 subjects.

2.4. Genotyping Method. The genotype data from PCR2 were used to infer subject haplotypes using haplotyping table revised from Rieder et al. [9] (Table 1). A subject may have a homozygous (e.g., H1H1) or heterozygous haplotype (e.g., $\mathrm{H} 1 \mathrm{H} 7)$.

2.5. Sequencing. All PCR products were analysed by agarose gel electrophoresis (1\%). The expected band sizes are listed in Tables 2 and 3. PCR amplification products for PCR2 were sent to a commercial laboratory for sequencing. Sequencing was performed using an Applied Biosystems 3730 XL Genetic Analyzer (Applied Biosystems, Foster City). The SNPs were analysed by aligning the result sequence with the reference gene sequence AY587020 using the BioEdit Sequence Alignment Editor (version 7.0.5.3).

\section{Results}

The optimised reagent concentrations for both PCR1 and PCR2 are similar except for the primer pair concentration for PCR1 which is $0.60 \mu \mathrm{M}$ for VKORC1 381 and 861 and $0.25 \mu \mathrm{M}$ for both VKORC1 5808 and 9041. In PCR2, the primer pair concentrations were $0.70,0.05,0.09$, and $0.06 \mu \mathrm{M}$ 
TABLE 1: The four SNPs required to infer the VKORC1 haplotypes. The replacement of VKORC1 381 with VKORC1 3673, 6484, 6853, or 7566 was possible because these five SNPs were tightly linked.

\begin{tabular}{lccc}
\hline VKORC1 SNP & HGSV & WT variant & Haplotype \\
\hline 381 & $296 \mathrm{C}>\mathrm{T}$ & $\mathrm{C}=$ see 5808 & Mut variant \\
5808 & $5723 \mathrm{~T}>\mathrm{G}$ & $\mathrm{T}=\mathrm{H} 1$ & $\mathrm{Tee} 9041$ \\
9041 & $8956 \mathrm{G}>\mathrm{A}$ & $\mathrm{G}=\mathrm{H} 9$ & $\mathrm{G}=\mathrm{H} 2$ \\
861 & $776 \mathrm{C}>\mathrm{A}$ & $\mathrm{C}=\mathrm{H} 7$ & $\mathrm{~A}=$ see 861 \\
& & $\mathrm{~A}=\mathrm{H} 8$ \\
\hline
\end{tabular}

TABle 2: Primers used in PCR1 and PCR2.

\begin{tabular}{|c|c|c|c|c|c|}
\hline & Sequence $\left(5^{\prime}\right.$ to $\left.3^{\prime}\right)$ & Location & Length (bp) & Product size (bp) & $T_{m}\left({ }^{\circ} \mathrm{C}\right)$ \\
\hline \multicolumn{6}{|l|}{ Primers for PCRI } \\
\hline \multicolumn{6}{|l|}{$381 \& 861$} \\
\hline Com (F) & GCCCAGGAGTTAGAGGCAACATAAC & $257-281$ & 25 & 1060 & 66.2 \\
\hline Com (R) & CAGCTTTCTCTGATCTCCTGGTGTG & $1316-1292$ & 25 & & 66.2 \\
\hline \multicolumn{6}{|c|}{ ( } \\
\hline $\operatorname{Com}(\mathrm{F})$ & ATTCTGGAGTCTGGGATCGGTGTG & 5546-5569 & 24 & 398 & 66.3 \\
\hline $\operatorname{Com}(\mathrm{R})$ & ACССCAGAATCTCCAGСТСССТG & $5943-5921$ & 23 & & 68.1 \\
\hline \multicolumn{6}{|l|}{9041} \\
\hline $\operatorname{Com}(\mathrm{F})$ & CAGCTCCTGGCATCTAGGTAGTGC & $8604-8627$ & 24 & 853 & 68.0 \\
\hline $\operatorname{Com}(\mathrm{R})$ & СTTCCAGGTGTGTGCTCAGCCTTC & $9456-9433$ & 24 & & 68.0 \\
\hline \multicolumn{6}{|l|}{ Primers for PCR2 } \\
\hline \multicolumn{6}{|l|}{381} \\
\hline $381 \& 861$ Com (R) & CAGCTTTCTCTGATCTCCTGGTGTG & $1316-1292$ & 25 & & 66.2 \\
\hline $\mathrm{WT}(\mathrm{F})$ & AGCACTTTAGGAAGCCAAGGAGGGC & $357-381$ & 25 & 960 & 67.9 \\
\hline Mut (F) & AGCACTTTAGGAAGCCAAGGAGGGT & $357-381$ & 25 & 960 & 66.2 \\
\hline \multicolumn{6}{|l|}{861} \\
\hline 381 \& 861 Com (R) & CAGCTTTCTCTGATCTCCTGGTGTG & $1316-1292$ & 25 & & 66.2 \\
\hline WT (F) & AAACTCCTGACCTCAGGTGATCCAC & $837-861$ & 25 & 480 & 66.2 \\
\hline Mut (F) & AAACTCCTGACCTCAGGTGATCCAA & $837-861$ & 25 & 480 & 64.6 \\
\hline \multicolumn{6}{|l|}{5808} \\
\hline $\operatorname{Com}(\mathrm{F})$ & ATTCTGGAGTCTGGGATCGGTGTG & $5546-5569$ & 24 & & 66.3 \\
\hline WT (R) & CGCCAACACСССССТTCA & $5825-5808$ & 18 & 280 & 71.7 \\
\hline Mut (R) & CGCCAACACСССССТТСС & $5825-5808$ & 18 & 280 & 70.8 \\
\hline \multicolumn{6}{|c|}{ 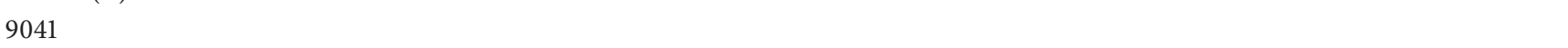 } \\
\hline Com (R) & CTTCCAGGTGTGTGCTCAGCCTTC & $9456-9433$ & 24 & & 68.0 \\
\hline WT (F) & ССТССТССТGССATACССG & $9023-9041$ & 19 & 434 & 66.6 \\
\hline Mut (F) & ССТССТССТGССАТАСССА & $9023-9041$ & 19 & 434 & 64.5 \\
\hline
\end{tabular}

for VKORC1 381, 861, 5808, and 9041, respectively. Thermal cycling conditions are similar for both PCR1 and PCR2 except for the annealing temperature for PCR1 which was at $63.5^{\circ} \mathrm{C}$, while for PCR2 it was at $64.8^{\circ} \mathrm{C}$. Both PCR reactions were run for 25 cycles. Optimised gel electrophoresis images for optimised multiplex PCR1 are shown in Figure 1, while the representative images for PCR2 are shown in Figure 2. The genotypes determined by the optimised PCR2 were in $100 \%$ concordance with the DNA sequencing data. The reproducibility of the method was confirmed by the successful amplification of all 92 additional DNA samples. Genotype and haplotype frequency for all of the subjects are shown in Table 3 . The haplotypes in 31 subjects could not be accurately determined whether as $\mathrm{H} 1 \mathrm{H} 7$ or $\mathrm{H} 1 \mathrm{H} 9$ because they were heterozygous for both VKORC1 381 and 9041, leading to inconclusive results from the haplotyping tree. The finding was comparable with what has been discovered by Lee et al. [10], where in this investigation the frequency of $\mathrm{H} 1 \mathrm{H} 1$ was $53.76 \%$ (compared with $42 \%$ ), $\mathrm{H} 1 \mathrm{H} 7$ or $\mathrm{H} 1 \mathrm{H} 9$ was $34.41 \%$ (compared with $42 \%$ ), H7H7 was $8.6 \%$ (compared with $8 \%$ ), 
TABLE 3: Genotype frequency of individual VKORC1 SNPs and haplotype frequency in 93 subjects.

\begin{tabular}{|c|c|c|c|}
\hline & \multicolumn{3}{|c|}{ Number of patients (\%) } \\
\hline & Homozygous wild type & Heterozygous & Homozygous mutant \\
\hline VKORC1 $381(\mathrm{C}>\mathrm{T})$ & $51(54.84)$ & $33(35.48)$ & $9(9.68)$ \\
\hline VKORC1 $861(\mathrm{C}>\mathrm{A})$ & $91(97.85)$ & $0(0)$ & $2(2.15)$ \\
\hline VKORC1 $5808(\mathrm{G}>\mathrm{A})$ & $92(98.92)$ & $1(1.08)$ & $0(0)$ \\
\hline \multirow[t]{2}{*}{ VKORC1 $9041(\mathrm{~T}>\mathrm{G})$} & $51(54.84)$ & $33(35.48)$ & $9(9.68)$ \\
\hline & \multicolumn{3}{|c|}{ Number of patients (\%) } \\
\hline $\mathrm{H} 1 \mathrm{H} 1$ & & $50(53.76)$ & \\
\hline $\mathrm{H} 1 \mathrm{H} 2$ & & $1(1.08)$ & \\
\hline $\mathrm{H} 1 \mathrm{H} 7^{\mathrm{a}}$ & & $1(1.08)$ & \\
\hline $\mathrm{H} 1 \mathrm{H} 7$ or $\mathrm{H} 1 \mathrm{H} 9^{\mathrm{a}}$ & & $31(33.33)$ & \\
\hline H1H9 & & $1(1.08)$ & \\
\hline $\mathrm{H} 7 \mathrm{H} 7$ & & $8(8.6)$ & \\
\hline $\mathrm{H} 8 \mathrm{H} 9$ & & $1(1.08)$ & \\
\hline
\end{tabular}

a"H1H7 or H1H9" was considered as "H1H7," in concordance with previous investigation findings, where H1H9 was uncommon in Asia.

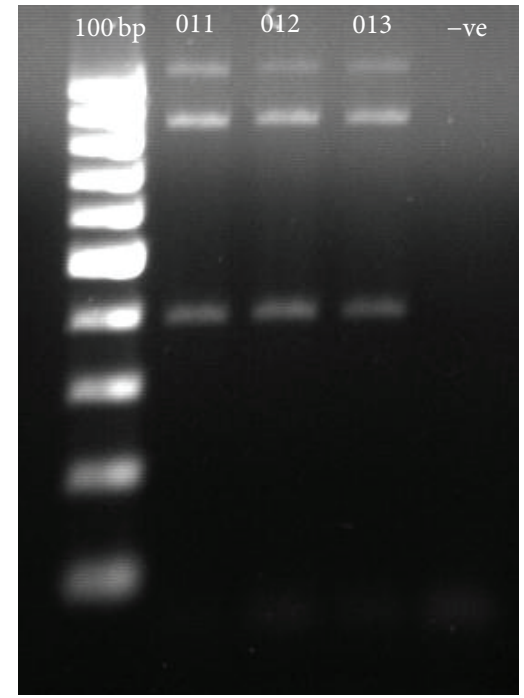

Figure 1: Optimised multiplex amplification for PCR1. $100 \mathrm{bp}$ : 100 bp ladder; -ve: negative control.

and the remaining haplotypes were $3.23 \%$ (compared with $0 \%)$.

\section{Discussion}

It is rather common for a multiplex PCR reaction to yield bands with unequal brightness. Therefore, individual samples, especially those which produced faint bands for VKORC1 381 in PCR1, can be reamplified using higher amounts of DNA template. For PCR2, the intensity of VKORC1 381 band was increased by reamplifying faint bands following the addition of $2.5 \%$ dimethyl sulfoxide (DMSO) into the PCR mixture. However, even though the addition of DMSO improved the brightness of the VKORC1 381 band, the occurrence of nonspecific bands at the region of the $700 \mathrm{bp}$ also increased without compensating the readings.
Among the 93 tested patients, 31 patients had an unclear haplotype; that is, it could not be determined whether the patients were $\mathrm{H} 1 \mathrm{H} 7$ or $\mathrm{H} 1 \mathrm{H} 9$. For the purpose of comparison, it is safe to assume that the patients with unclear haplotype have haplotype $\mathrm{H} 1 \mathrm{H} 7$ due to the absence of $\mathrm{H} 1 \mathrm{H} 9$ haplotype in previous investigations [10, 11]. Nevertheless, a measure to improve the distinction between $\mathrm{H} 1 \mathrm{H} 7$ and $\mathrm{H} 1 \mathrm{H} 9$ is still possible by adding another VKORC1 variant primer pair such as VKORC1 6484 (also known as VKORC1 $1173 \mathrm{C}>\mathrm{T}$ ) which has been found to be present in complete linkage disequilibrium together with VKORC1 9041 [20] into PCR2 amplifications which can be further investigated in future studies. Other than VKORC1 381 (and its linked alleles), $V K O R C 15808$ also played a major role in determining the $V K O R C 1$ haplotype. In a previously reported simple method for determining VKORC1 haplotypes [11], any heterozygous $\mathrm{H} 1$ haplotype was assumed to be $\mathrm{H} 1 \mathrm{H} 7$ (combination of low and high dosage requirement) because other possible haplotypes like $\mathrm{H} 1 \mathrm{H} 8$ and $\mathrm{H} 1 \mathrm{H} 9$ haplotype are exceptionally rare in the Asian population. However, the oversimplified genotyping method was shown to cause overestimation of daily warfarin dose [11], which proved that each of $\mathrm{H} 7$, H8, and H9 may affect the warfarin dose differently, even though three of the haplotypes were classified under the same "high warfarin dose" group [9]. The finding also supports that the occurrence of rare haplotypes like $\mathrm{H} 8$ and $\mathrm{H} 9$ was still possible in the Asian population. Therefore, additional identification of other VKORC1 SNPs in addition to VKORC1 381 is an essential step that should not be overlooked.

Malaysia is a country which consists of three major ethnic groups, namely, the Malays, Chinese, and the Indians with distinct genotypic frequency and polymorphisms. In this study, only VKORC1 polymorphisms among the Malay populations were investigated since the Malay is the major ethnic group found in the study region (Kelantan). The Malay ethnic group, to some extent, can represent the genotypic distribution of the Chinese population due to reported similar polymorphic frequency in certain genes [21]. The Indian population, however, is a very distinct ethnic group 


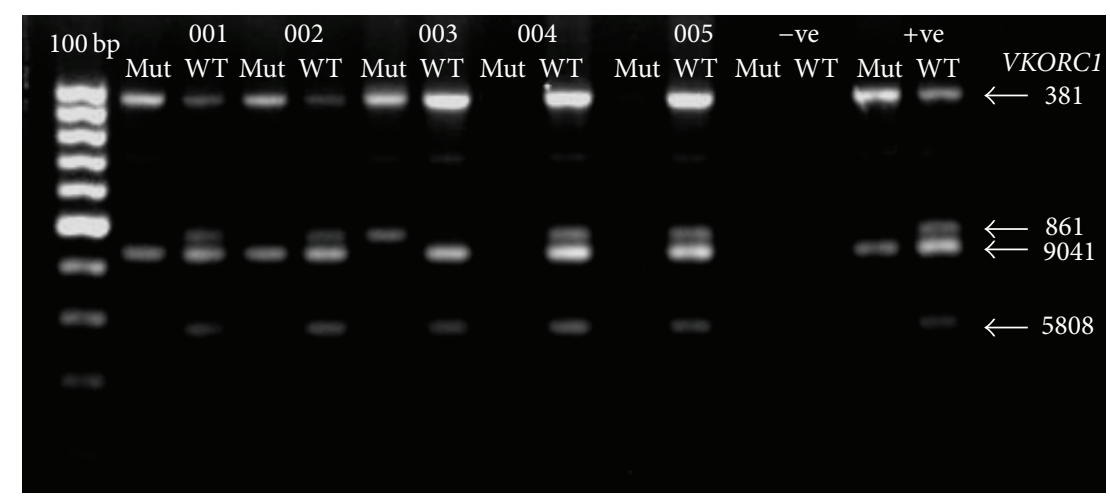

FIgURE 2: Representative gel electrophoresis result for PCR2. Genomic DNA from six unrelated subjects (001-005) was used as DNA templates. $100 \mathrm{bp}=100 \mathrm{bp}$ ladder; $-\mathrm{ve}=$ negative control; +ve = positive control.

where certain warfarin-related mutant strain SNPs such as the CYP2C9*2 and $* 3$ and $V K O R C 1-1639 \mathrm{G}$ were reported to be higher in frequency among the Indians when compared with the Malays and the Chinese [22, 23]. Therefore, future studies investigating the VKORC1 haplotypes among the Indians are important to thoroughly represent the VKORC1 haplotype in the Malaysian population.

All VKORC1 genotypic frequencies were found to be in Hardy-Weinberg equilibrium except for the VKORC1 861 $\mathrm{CA}$ and $\mathrm{AA}$ which may be underestimated (observed = 0 , expected $=0.29$ ) and overestimated (observed $=0.0215$, expected $=0$ ), respectively. This could be contributed by either the small sample size or the low frequency of the allele in this population (or both). Nevertheless, should the $861 \mathrm{CA}$ occur, the only possible haplotype for the subject is H7H8. A previous study [10] in an Asian population utilising similar sample size also found low frequencies of $\mathrm{H} 7 \mathrm{H} 8$. Therefore, future studies intending to investigate the frequency of the H7H8 haplotype will require much larger sample size to avoid deviation in Hardy-Weinberg equilibrium.

To our knowledge, this is the first PCR method that can simultaneously amplify multiple VKORC1 alleles. Although there are many PCR methods available for the genotyping of single VKORC1 SNPs, the prediction accuracy of multiple VKORC1 SNPs will certainly be superior to those of single SNP. The addition of only few primer pairs in genotyping proved to yield very detailed haplotype data when compared with genotypic data generated by singleSNP PCR. This multiplex PCR method is an advantage especially for laboratories which are not equipped with automated sequencers. Otherwise, direct sequencing of the whole (small-sized) VKORC1 gene would be the method of choice for haplotyping patients under warfarin treatment in order to detect rare but potentially unknown variants in VKORC1. Moreover, the developed method was economical and can be conducted using only basic molecular tools that are available in most laboratories. The haplotyping method is easy to use and allows the VKORC1 gene to be haplotyped without the necessity of whole-gene sequencing. This method was successfully used to investigate the frequency of VKORC1 haplotypes in a small group of Malaysian patients.

\section{Conflict of Interests}

The authors declare that there is no conflict of interests regarding the publication of this paper.

\section{Acknowledgments}

This study was supported by Universiti Sains Malaysia short term Grant (304/PPSP/61312019). The authors would like to thank Mdm. Che Rosnani binti Awang at the Specialised Medicine Clinic of the Hospital Universiti Sains Malaysia for her help with sample collection.

\section{References}

[1] M. K. Higashi, D. L. Veenstra, L. Midori Kondo et al., "Association between CYP2C9 genetic variants and anticoagulationrelated outcomes during warfarin therapy," Journal of the American Medical Association, vol. 287, no. 13, pp. 1690-1698, 2002.

[2] D. L. Veenstra, J. H. S. You, M. J. Rieder et al., "Association of Vitamin K epoxide reductase complex 1 (VKORC1) variants with warfarin dose in a Hong Kong Chinese patient population," Pharmacogenetics and Genomics, vol. 15, no. 10, pp. 687-691, 2005.

[3] M. D. Caldwell, R. L. Berg, Q. Z. Kai et al., "Evaluation of genetic factors for warfarin dose prediction," Clinical Medicine and Research, vol. 5, no. 1, pp. 8-16, 2007.

[4] Y. Zhu, M. Shennan, K. K. Reynolds et al., "Estimation of warfarin maintenance dose based on $\operatorname{VKORC1}(-1639 \mathrm{G}>\mathrm{A})$ and CYP2C9 genotypes," Clinical Chemistry, vol. 53, no. 7, pp. 11991205, 2007.

[5] P. Lenzini, M. Wadelius, S. Kimmel et al., "Integration of genetic, clinical, and INR data to refine warfarin dosing," Clinical Pharmacology and Therapeutics, vol. 87, no. 5, pp. 572-578, 2010.

[6] Maryland: US Food and Drug Administration, FDA approves updated warfarin (Coumadin) prescribing information: New genetic Information may help providers improve initial dosing estimates of the anticoagulant for individual patients, http://www.fda.gov/NewsEvents/Newsroom/PressAnnouncements/2007/ucm108967.htm. 
[7] T. Li, C.-Y. Chang, D.-Y. Jin, P.-J. Lin, A. Khvorova, and D. W. Stafford, "Identification of the gene for vitamin K epoxide reductase," Nature, vol. 427, no. 6974, pp. 541-544, 2004.

[8] S. Rost, A. Fregin, V. Ivaskevicius et al., "Mutations in VKORC1 cause warfarin resistance and multiple coagulation factor deficiency type 2," Nature, vol. 427, no. 6974, pp. 537-541, 2004.

[9] M. J. Rieder, A. P. Reiner, B. F. Gage et al., "Effect of VKORC1 haplotypes on transcriptional regulation and warfarin dose," The New England Journal of Medicine, vol. 352, no. 22, pp. 22852293, 2005.

[10] S.-C. Lee, S.-S. Ng, J. Oldenburg et al., "Interethnic variability of warfarin maintenance requirement is explained by VKORC1 genotype in an Asian population," Clinical Pharmacology and Therapeutics, vol. 79, no. 3, pp. 197-205, 2006.

[11] L.-S. Tham, B.-C. Goh, A. Nafziger et al., "A warfarin-dosing model in Asians that uses single-nucleotide polymorphisms in vitamin $\mathrm{K}$ epoxide reductase complex and cytochrome $\mathrm{P} 450$ 2C9," Clinical Pharmacology and Therapeutics, vol. 80, no. 4, pp. 346-355, 2006.

[12] G. D’Andrea, R. L. D’Ambrosio, P. di Perna et al., "A polymorphism in the VKORCl gene is associated with an interindividual variability in the dose-anticoagulant effect of warfarin," Blood, vol. 105, no. 2, pp. 645-649, 2005.

[13] H.-Y. Yuan, J.-J. Chen, M. T. M. Lee et al., "A novel functional VKORC1 promoter polymorphism is associated with interindividual and inter-ethnic differences in warfarin sensitivity," Human Molecular Genetics, vol. 14, no. 13, pp. 1745-1751, 2005.

[14] E. A. Sconce, T. I. Khan, H. A. Wynne et al., "The impact of CYP2C9 and VKORC1 genetic polymorphism and patient characteristics upon warfarin dose requirements: proposal for a new dosing regimen," Blood, vol. 106, no. 7, pp. 2329-2333, 2005.

[15] A. J. Rai, N. Udar, R. Saad, and M. Fleisher, "A multiplex assay for detecting Genetic variations in cyp2c9, vkorc1, and GGCX involved in warfarin metabolism," Clinical Chemistry, vol. 55, no. 4, pp. 823-826, 2009.

[16] M. J. Rieder, A. P. Reiner, and A. E. Rettie, " $\gamma$-Glutamyl carboxylase (GGCX) tagSNPs have limited utility for predicting warfarin maintenance dose," Journal of Thrombosis and Haemostasis, vol. 5, no. 11, pp. 2227-2234, 2007.

[17] Y. Miyagata, K. Nakai, and Y. Sugiyama, "Clinical significance of combined CYP2C9 and VKORC1 genotypes in Japanese patients requiring warfarin," International Heart Journal, vol. 52, no. 1, pp. 44-49, 2011.

[18] R. Howard, J. B. S. Leathart, D. J. French et al., "Genotyping for CYP2C9 and VKORC1 alleles by a novel point of care assay with HyBeacon probes," Clinica Chimica Acta, vol. 412, no. 23-24, pp. 2063-2069, 2011.

[19] S.-W. Huang, Q. Li, S.-Y. Zhu et al., "SYBR Green-based realtime PCR assay for detection of VKORC1 and CYP2C9 polymorphisms that modulate warfarin dose requirement," Clinical Chemistry and Laboratory Medicine, vol. 47, no. 1, pp. 26-31, 2009.

[20] K. Kosaki, C. Yamaghishi, R. Sato et al., "1173C > T polymorphism in VKORC1 modulates the required warfarin dose," Pediatric Cardiology, vol. 27, no. 6, pp. 685-688, 2006.

[21] Z. Zainuddin, L. K. Teh, A. W. M. Suhaimi, and R. Ismail, "Malaysian Indians are genetically similar to Caucasians: CYP2C9 polymorphism," Journal of Clinical Pharmacy and Therapeutics, vol. 31, no. 2, pp. 187-191, 2006.

[22] K. C. Seng, G. G. Gin, J. V. Sangkar, and M. E. Phipps, "Frequency of cytochrome P450 2C9 (CYP2C9) alleles in three ethnic groups in Malaysia," Asia-Pacific Journal of Molecular Biology and Biotechnology, vol. 11, no. 2, pp. 83-91, 2003.

[23] G. G. Gan, M.-T. M. Lee, R. Subramaniam, L.-S. Lu, M. C. Tai, and M. E. Phipps, "Allele and genotype frequencies of VKORC1 $-1639 \mathrm{~g}>$ a polymorphism in three different ethnic groups in Malaysia," Asia-Pacific Journal of Molecular Biology and Biotechnology, vol. 20, no. 1, pp. 19-23, 2012. 

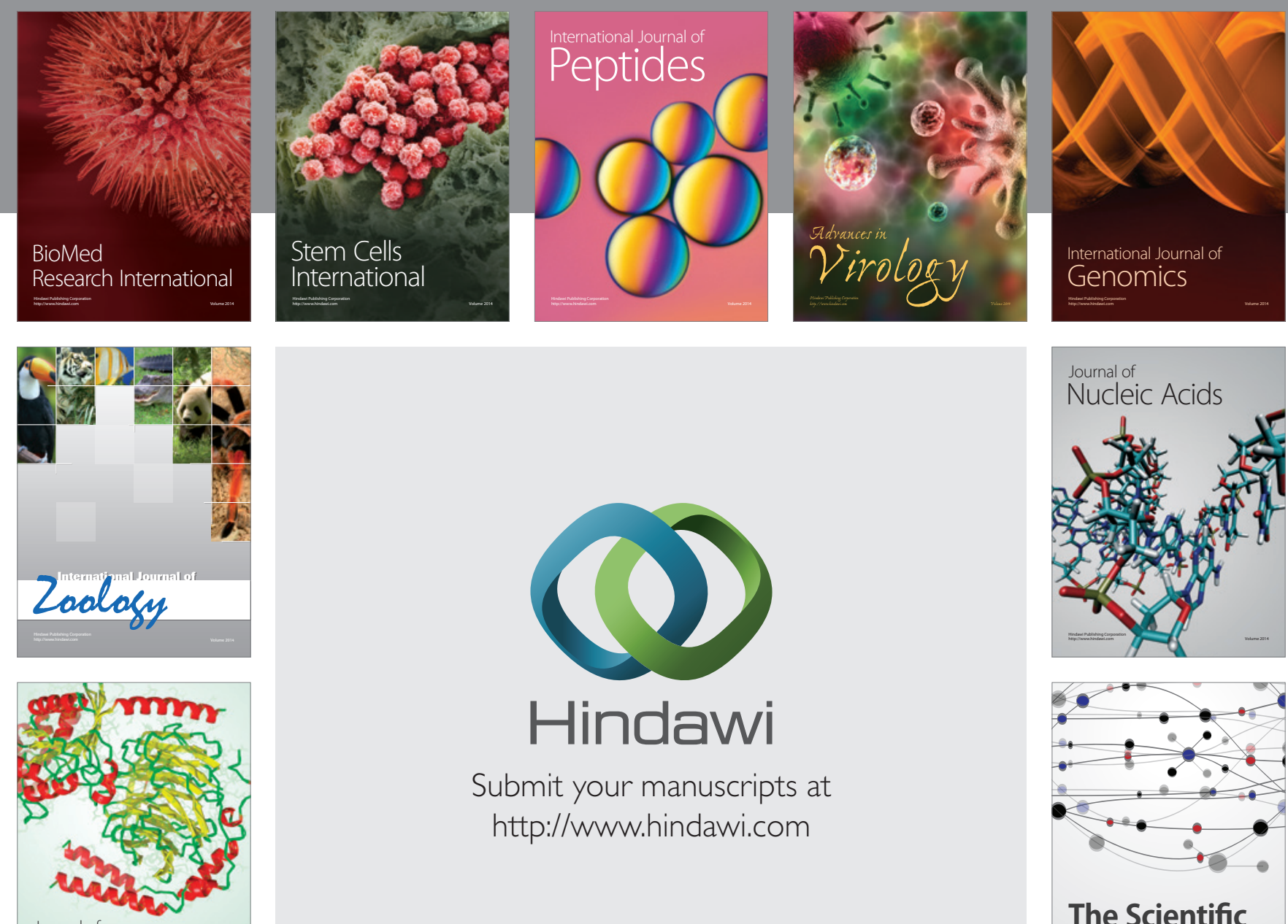

Submit your manuscripts at

http://www.hindawi.com

Journal of
Signal Transduction
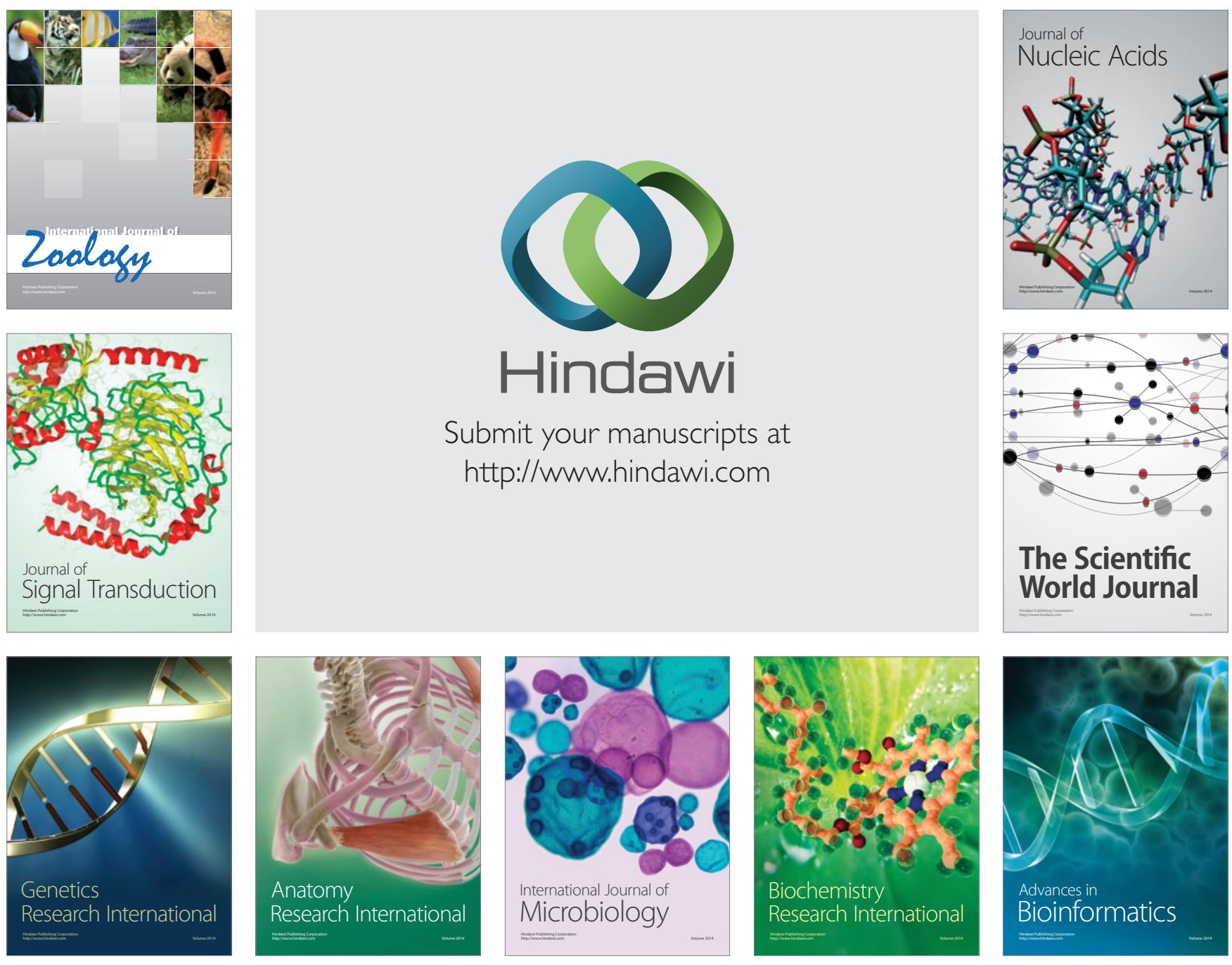

The Scientific World Journal
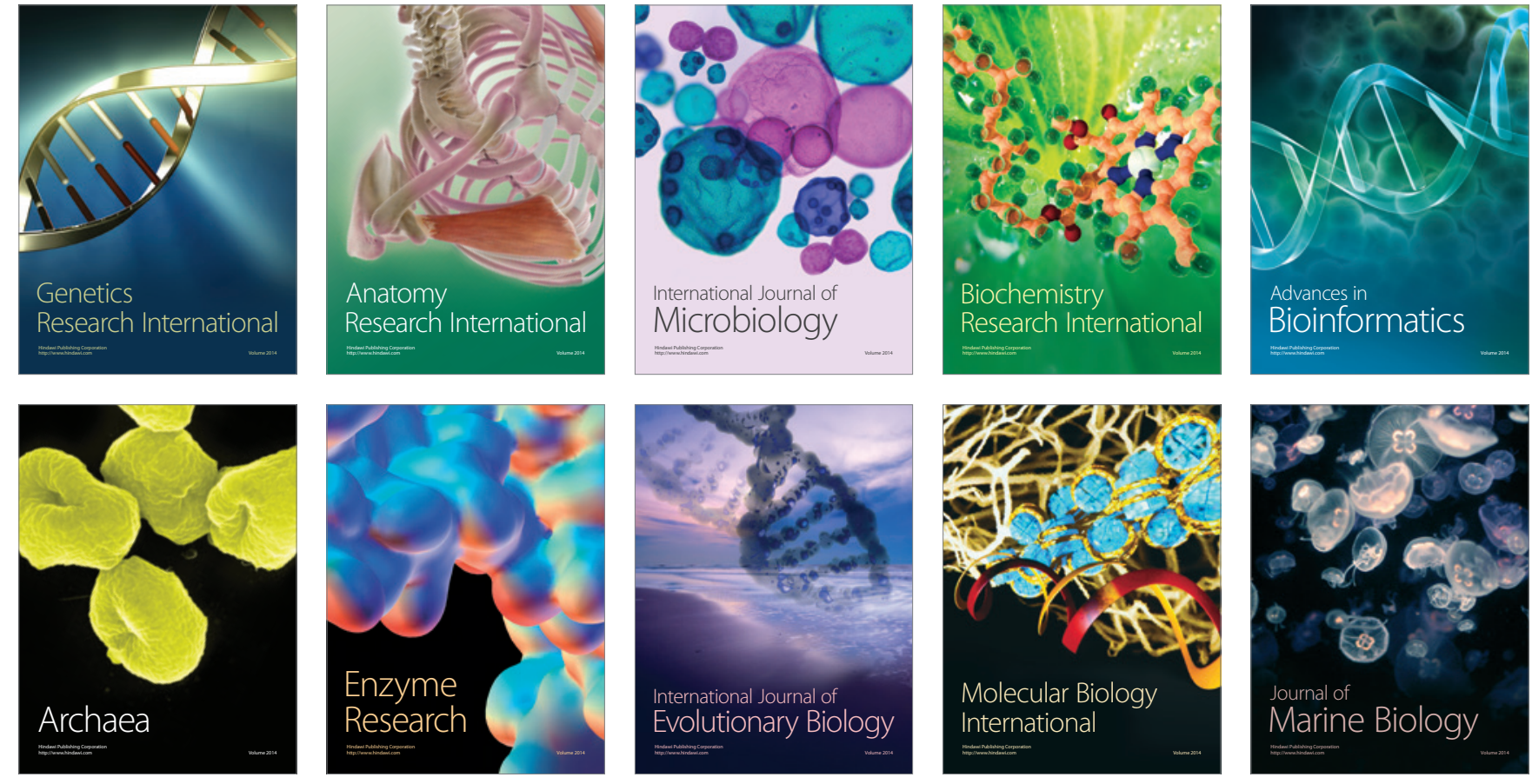